\title{
Effect of Arbuscular Mycorrhizal Fungi Based Biofertilizer on Coconut Seedlings Growth in Nursery
}

\author{
S.H.S. Senarathne and I.M.P.S. Ilangamudali
}

\begin{abstract}
The success of a coconut plantation, in terms of its field establishment as well as its future performance, is heavily dependent on the quality of the seedlings used. Coconut nurseries adopt different agronomic practices to produce good quality seedlings. Applying mycorrhizal inoculants is becoming an increasingly common practice in plant nurseries as it facilitates healthy seedling growth resulting in healthy and vigorous seedlings in the nursery, helps to reduce mortality rates of seedlings in the field and reduce water and fertilizer consumption. In this study effects of mycorrhizae based biofertilizer were evaluated for the growth of coconut seedlings in the nursery and field. The experiment was conducted at the Makadura Research Center in Sri Lanka. The nursery experiment treatments were, the presence of AMF based biofertilizer (50g per seedling or per bag) and absence of mycorrhizae based biofertilizer. In the field experiment, five treatments with $500 \mathrm{~g}$ of AMF biofertilizerwith $25 \%$ recommended inorganic fertilizer mixture for young coconut palms (YPM) per seedling, 500g of AMF biofertilizer with 50\% YPM per seedling, 500g of AMF biofertilizer with $75 \%$ YPM per seedling, 500g of AMF biofertilizer with 100\% YPM per seedling and with only YPM per seedling. Root and shoot growth of seedlings were measured at monthly intervals in the nursery experiment. Leaf production rate and stem girth of the seedling were measured at six months interval in the field experiment. The application of bio fertilizer increased the volume and dry weight of primary, secondary, tertiary and quaternary roots in seedlings in the nursery significantly. A significantly higher leaf production rate and stem girth was observed in the field seedlings treatment with $500 \mathrm{~g}$ of AMF biofertilizer with 75\% YPM. The experiment concluded that application of bio fertilizer is beneficial for coconut seedlings in the nursery for the production good quality seedlings with well-developed roots resulting in better field establishment and in the field for fast and vigorous growth.
\end{abstract}

Key words: AMF bio-fertilizer, coconut, roots and shoots growth

Running title: AMF bio-fertilizer on coconut seedling growth

Agronomy Division, Coconut Research Institute, Lunuwila, Sri Lanka.

Email: shsumith71@yahoo.com \& sachithya@gmail.com 


\section{Introduction}

Generally, maintenance of new or senile coconut plantations with handling of improper genetic materials has largely contributed to low productivity of coconut plantations. One of the main reasons for this high motility rate of seedling is low vigor, especially less developed root and shoots system. Under this condition, planting of coconut plantations with quality seedlings needs to be promoted and to maintain a proper coconut plantation, high quality coconut seedlings must be used as it helps to establish a healthy and uniform plantation. This is a critical point of coconut cultivation. Thus, nursery management techniques play an important role in coconut cultivation in producing high quality planting materials that will ultimately provide higher yields (Menon and Pandalai, 1958). Standardized nursery techniques help in producing large quantities of quality seedlings at relatively low costs (Menon and Pandalai, 1958). Among the cultural practices in coconut nurseries, irrigation, manuring and weeding are considered to be crucial.During the nursery period, inorganic fertilizers are applied to increase the seedling growth and to overcome nutrient deficiencies. However, applying mycorrhizal inoculants is becoming an increasingly common practice in plant nurseries. Whether nurseries are producing native, ornamental, or agricultural plants, adding mycorrhizae can lower mortality rates of plants and reduce water and fertilizer consumption (Coyne and Mark, 1999). There are many ways that mycorrhizae facilitate healthy plant growth and finally help to produce quality seedlings in the nursery (Linderman and Davis, 2004).

Mycorrhizal technology plays vital role in sustainable plant-soil ecosystems (Jeffries and Barea, 2000; Gianinazziet al., 2002). Mycorrhizae can increase the surface area of a plant root system (Miller and Jastrow, 1992) as a result; the plant is able to absorb more water and nutrients. This increase in water uptake increases the survival of transplants and facilitates drought resistance. In most cases, mycorrhizae increase a plant's access to nutrients such as phosphorus and zinc, which is important in tropical soils where phosphorus availability is low (Gemma and Koske, 2006). In addition, mycorrhizae can increase nitrogen fixation in nodule-forming plants (Kemery and Dana, 1995). Plants that receive proper nutrition'sare able to resist diseases, and this is one way that mycorrhizae help plants to prevent from soil borne disease infections (Linderman and Davis, 2004). The most obvious mechanism for protection against diseases is the barrier that Ectomycorrhizae create when they coat the external surface of the root (Castellano and Molina, 1989). Mycorrhizae compete with pathogenic microorganisms and antibiotics to protect the plants and also root feeding nematodes are less likely to attack mycorrhizal plants (Atimanav and Adholeya, 2002). Other benefits include improved soil structure due to the mycorrhizae binding soil particles into aggregates - allowing water to infiltrate and increasing oxygen in the rhizosphere (Coyne and Mark, 1999). Incorporation of bio fertilizers which contain Arbuscular Mycorrhizal fungi (AMF) during the nursery period without incurring costs in supplying inorganic fertilizers can be an effective way of enhancing shoot and root growth (Marx et al., 1989).

In this experiment, the biofertilizer "MYCOgold" was tested. It is produced by MALAYSIAN AGRI CARE SND. BHD. Company in Malaysia. Commercial name was; MYCOgold. It contains mycirrhizalhypae, infected root bits and viable spores with sterilized sand as the carrier medium.It contains $95 \%$ of endo-mycorrhizal spores and $5 \%$ of additives that assist in prolonging the shelf life of mycorrhiza in MYCOgold. These additives also assist in improving the efficiency of MYCOgold in the field. MYCOgold contain four genuses of endomycorrhizal spores, such as Acaulospora, Gigaspora, Scutellospora. Also it contains sterilized sand and vermiculite. However no research had been carried out on AMF base bio fertilizers to understand its activity on root and shoot growth in coconut seedlings. This study was carried out to determine the impact of an AMF containing biofertilizer on coconut seedling growth in the nursery and the field conditions. 


\section{Materials and methods}

\section{Nursery experiment}

The nursery experiment was carried out at the Bandirippuwa Estate of the Coconut Research Institute of Sri Lanka which is located in the Intermediate Zone Low Country $\left(\mathrm{IL}_{1} \mathrm{a}\right)$ from November 2013 to July 2014. The mean annual rainfall was $1660 \mathrm{~mm}$ with fluctuation during dry periods. During the experimental period, the ambient air and soil temperature ranges between $28^{\circ} \mathrm{C}$ to $32^{\circ} \mathrm{C}$ and bright sunshine hours vary from 6 to 8 hours per day. The site was located in a well-drained flat land area without shade. Poly bags of $75 \mathrm{~cm}$ in height and $45 \mathrm{~cm}$ in width made of 500 gauges black polythene with gussets were used. Few punch holes were pierced on all sides close to the bottom to drain the excess water. The nursery stage poly bagged coconut seedlings were used in this study. The poly bags were filled with a potting mixture made up of coir dust and soil in a ratio of $3: 1$. High ratio of coir dust facilitates the uprooting of coconut seedlings without root damage. Coconut seedlings ( 2 months aged, tall $\mathrm{x}$ tall variety) were planted in individual poly bags and arranged at a spacing of $60 \mathrm{~cm} \times 60 \mathrm{~cm}$ in two separate plots according to the treatments. The experimental design was a Complete Randomized Design with five replicates. The experiment consisted of two bio fertilizer treatments with Arbuscular Mycorrhizal Fungi (AMF) based biofertilizer $\left(\mathrm{T}_{1}\right)$ and without Arbuscular Mycorrhizal Fungi (AMF) based bio fertilizer $\left(\mathrm{T}_{2}\right)$. Fifty gram (50 g per seedling) of AMF base bio fertilizer (Commercial name: MYCOgold) was mixed well with the potting media at the time of planting seed nuts. All seedlings were managed by following the recommended nursery practices. The seedlings were maintained at near field capacity by watering at 3 days intervals in the absence of rainfall. Weed and pest control was done manually as per the recommendation of CRISL.

\section{Sampling and sample preparation}

Destructive samples were taken at four weekly intervals. At each sampling, four coconut seedlings were uprooted randomly from each treatment. First, seedling girth and seedling height were measured. Thereafter, the poly bag was removed and the potting mixture was washed away without damaging the roots, using running water. The coconut husk of the seed nut was carefully removed using a sharp knife. All the roots within the husk were removed and separated in to primary, secondary, tertiary and quaternary roots.

\section{Root measurements}

The root volume ( $\mathrm{ml})$ was taken by using the Archimedes principle (Burdette, 1979). A specific measuring cylinder was used to measure the displaced water volume. The separated root samples; primary, secondary, tertiary and quaternary roots, were immersed in a known volume of water in order to measure the displaced water volume.

$\begin{array}{llc} & \text { Displaced water } & \\ \text { Root volume } & \begin{array}{l}\text { volume }(\mathrm{ml}) \mathrm{by} \\ \text { known volume }\end{array} & \text {-Known volume } \\ (\mathrm{ml})= & \begin{array}{l}\text { and roots } \\ \text { and }\end{array}\end{array}$

Separated root samples were oven dried at $80^{\circ} \mathrm{C}$ to a constant weight. Dry weights $(\mathrm{g})$ of the different categories of roots were recorded.

\section{Shoot measurements in nursery experiment}

To measure the leaf area, leaves were separated from the petiole and cut into pieces and leaf area was measured with an Automatic Leaf Area meter (USA LI COR 3100). Then the leaf petiole pieces were oven dried at $80^{\circ} \mathrm{C}$ temperature to a constant weight and total shoot dry weight was determined.

\section{Field experiment}

The field experiment was carried out at the Sub Research Station, Makadura, in the Low Country Intermediate Zone of North Western Province of Sri Lanka from December 2012 to December 2014. The station is located at $07^{0} 19^{\prime}$ south latitude, $79^{\circ} 59^{\prime}$ west longitudes, at $20 \mathrm{~m}$ above sea level in a moist humid tropical ecosystem. The area is characterized by bi-modal pattern of rainfall with an annual mean precipitation of $1800 \mathrm{~mm}$. approximately, 65\% of the annual rainfall is received from September to February (Maha). There is a smaller peak of 
rainfall from March to May (Yala), but the rainfall is erratic.Higher ambient air and soil temperatures (about $28^{\circ} \mathrm{C}-32^{\circ} \mathrm{C}$ ) and bright sunshine hours (about $6-8$ hours per day) are more common especially during the dry periods from May to September. The soil at the site was an Aluvial deep $(>120 \mathrm{~cm})$ and well to moderately drained. Surface soil is dark greyish brown with a sandy loam texture. Reaction of the soil is slightly acidic (pH 6.0 - 6.5) throughout the soil profile (Mapa et al., 2005). The experiment was established in newly established uniform coconut seedling block which was regularly fertilized with Young Palm Mixture with $500 \mathrm{~g}$ of Dolomite. All the coconut seedlings were well managed by following the recommended practices. Weed control was done manually.Pest and disease incidences were controlled. Experimental treatments were arranged in a Complete Randomized Design (CRD) with five replicates. The experiment consisted of five bio fertilizer treatments with $500 \mathrm{~g}$ of AMF biofertilizer with $25 \%$ recommended inorganic fertilizer mixture for young coconut palms (YPM) $\left(\mathrm{T}_{1}\right), 500 \mathrm{~g}$ of AMF biofertilizer with $50 \%$ YPM $\left(\mathrm{T}_{2}\right), 500 \mathrm{~g}$ of AMF biofertilizer with $75 \%$ YPM $\left(\mathrm{T}_{3}\right), 500 \mathrm{~g}$ of AMF biofertilizer with $100 \%$ YPM $\left(\mathrm{T}_{4}\right)$ and with only YPM $\left(\mathrm{T}_{5}\right)$. AMF base bio fertilizer (Commercial name: MYCOgold) (500g) were measured and add to the coconut seedling manure circle and mixed well with the manure circle soil. Inorganic fertilizers were added according to the treatments.

\section{Shoot measurements in field experiment}

Seedling girth $(\mathrm{cm})$ was measured using measuring tape at the point of shoot emergence from the nut and the number of new leaf production was counted at six month interval.

\section{Data analysis}

Experimental data were analysed following Analysis of Variance (ANOVA) procedure using the statistical software SAS (SAS reference) and the significance of the differences between means was tested using Least Significant Differences (LSD) at $\mathrm{P}=0.05$ (SAS Institute 1999).

\section{Results}

Effect of AMF bio-fertilizer on root development (dry weight) of coconut seedlings

Dry weight of primary roots of inoculated and non-inoculated seedlings were not significantly different $(\mathrm{P}<0.05)$ during the first fifth months (Table 1). Thereafter, seedlings treated with the inoculum had a significantly higher root dry weights when compared to the non-treated seedlings until end of the nursery period. The dry weight of secondary roots of seedlings were not significantly different $(\mathrm{P}<0.05)$ between two treatments during the first six months (Table 2).

A very little amount of tertiary roots were observed at the first sampling in both treatments but there were greater tertiary root dry weight in inoculated seedlings at the rest of the samplings when compared to the non-inoculated seedling. However, significantly higher tertiary root dry weights were observed in seedlings treated with the inoculum after fifth months of application when compared with non-inoculated seedlings (Table 3).

Seedlings did not have any quaternary roots in the first and second months. However, it was high in inoculated seedling when compared with the non-inoculated seedlings from the fourthmonth onwards. Significantly higher quaternary root dry weights were observed in inoculated seedlings compared to non-inoculated seedlings after the $4^{\text {th }}$ month (Table 4 ). Total root dry weight was greater in the seedlings treated with inoculums when compared with the noninoculated seedlings at all other samplings. From the fifth month, total root dry weights were significantly higher in inoculated seedlings than non-inoculated seedlings (Table 5).

\section{Effect of AMF base bio-fertilizer on root development (root volume) of coconut seedlings}

The volume of primary roots was not significant $(\mathrm{P}<0.05)$ between two treatments during the first five months (Table 6). From the fourth month onwards, seedlings treated with the AMF inoculum had larger primary roots, as depicted by the volume, when compared to the 
Table 1: Effect of AMF base bio-fertilizer on primary root dry weight (g) of coconut seedlings

\begin{tabular}{|c|c|c|c|c|c|c|c|}
\hline \multirow{2}{*}{ Treatments } & \multicolumn{7}{|c|}{ Time (after treatment application) } \\
\cline { 2 - 8 } & $\begin{array}{c}1^{\text {st }} \\
\text { Month }\end{array}$ & $\begin{array}{c}2^{\text {nd }} \\
\text { Month }\end{array}$ & $\begin{array}{c}3^{\text {rd }} \\
\text { Month }\end{array}$ & $\begin{array}{c}4^{\text {th }} \\
\text { Month }\end{array}$ & $\begin{array}{c}5^{\text {th }} \\
\text { Month }\end{array}$ & $\begin{array}{c}6^{\text {th }} \\
\text { Month }\end{array}$ & $\begin{array}{c}7^{\text {th }} \\
\text { Month }\end{array}$ \\
\hline $\mathrm{T}_{1}$ & 2.52 & 5.20 & 7.55 & 16.42 & 18.66 & 27.84 & 24.95 \\
\hline $\mathrm{T}_{2}$ & 2.96 & 6.41 & 5.43 & 11.19 & 18.63 & 20.50 & 17.81 \\
\hline Significance & $\mathrm{ns}$ & $\mathrm{ns}$ & $\mathrm{ns}$ & $\mathrm{ns}$ & $\mathrm{ns}$ & $*$ & $*$ \\
\hline LSD & - & - & - & - & - & 7.15 & 5.81 \\
\hline
\end{tabular}

*Denote the significant difference at $\mathrm{P}<0.05$; ns denote the non-significance

Table 2: Effect of AMF base bio-fertilizer on secondary root dry weight (g) of coconut seedlings

\begin{tabular}{|c|c|c|c|c|c|c|c|}
\hline \multirow{2}{*}{ Treatments } & \multicolumn{7}{|c|}{ Time (after treatment application) } \\
\cline { 2 - 8 } & $\begin{array}{c}1^{\text {st }} \\
\text { Month }\end{array}$ & $\begin{array}{c}2^{\text {nd }} \\
\text { Month }\end{array}$ & $\begin{array}{c}3^{\text {rd }} \\
\text { Month }\end{array}$ & $\begin{array}{c}4^{\text {th }} \\
\text { Month }\end{array}$ & $\begin{array}{c}5^{\text {th }} \\
\text { Month }\end{array}$ & $\begin{array}{c}6^{\text {th }} \\
\text { Month }\end{array}$ & $\begin{array}{c}7^{\text {th }} \\
\text { Month }\end{array}$ \\
\hline $\mathrm{T}_{1}$ & 0.96 & 1.74 & 1.76 & 4.25 & 7.09 & 7.93 & 10.98 \\
\hline $\mathrm{T}_{2}$ & 0.71 & 1.92 & 1.72 & 3.23 & 3.12 & 5.81 & 5.87 \\
\hline Significance & $\mathrm{ns}$ & $\mathrm{ns}$ & $\mathrm{ns}$ & $\mathrm{ns}$ & $\mathrm{ns}$ & $\mathrm{ns}$ & $*$ \\
\hline LSD & - & - & - & - & - & - & 5.011 \\
\hline
\end{tabular}

*Denote the significant difference at $\mathrm{P}<0.05$; ns denote the non-significance

Table 3: Effect of AMF base bio-fertilizer on tertiary root dry weight (g) of coconut seedlings

\begin{tabular}{|c|c|c|c|c|c|c|c|}
\hline \multirow{2}{*}{ Treatments } & \multicolumn{7}{|c|}{ Time (after treatment application) } \\
\cline { 2 - 8 } & $\begin{array}{c}1^{\text {st }} \\
\text { Month }\end{array}$ & $\begin{array}{c}2^{\text {nd }} \\
\text { Month }\end{array}$ & $\begin{array}{c}3^{\text {rd }} \\
\text { Month }\end{array}$ & $\begin{array}{c}4^{\text {th }} \\
\text { Month }\end{array}$ & $\begin{array}{c}5^{\text {th }} \\
\text { Month }\end{array}$ & $\begin{array}{c}6^{\text {th }} \\
\text { Month }\end{array}$ & $\begin{array}{c}7^{\text {th }} \\
\text { Month }\end{array}$ \\
\hline $\mathrm{T}_{1}$ & 0.02 & 0.33 & 0.44 & 0.61 & 0.89 & 1.59 & 2.24 \\
\hline $\mathrm{T}_{2}$ & 0.06 & 0.30 & 0.36 & 0.60 & 0.74 & 1.00 & 0.79 \\
\hline Significance & ns & ns & ns & ns & ns & $*$ & $*$ \\
\hline LSD & - & - & - & - & - & 0.50 & 0.95 \\
\hline
\end{tabular}

*Denote the significant difference at $\mathrm{P}<0.05$; ns denote the non-significance 
Table 4: Effect of AMF base bio-fertilizer on quaternary root dry weight (g) of coconut seedlings

\begin{tabular}{|c|c|c|c|c|c|c|c|}
\hline \multirow{2}{*}{ Treatments } & \multicolumn{7}{|c|}{ Time (after treatment application) } \\
\cline { 2 - 8 } & $\begin{array}{c}1^{\text {st }} \\
\text { Month }\end{array}$ & $\begin{array}{c}2^{\text {nd }} \\
\text { Month }\end{array}$ & $\begin{array}{c}3^{\text {rd }} \\
\text { Month }\end{array}$ & $\begin{array}{c}4^{\text {th }} \\
\text { Month }\end{array}$ & $\begin{array}{c}5^{\text {th }} \\
\text { Month }\end{array}$ & $\begin{array}{c}6^{\text {th }} \\
\text { Month }\end{array}$ & $\begin{array}{c}7^{\text {th }} \\
\text { Month }\end{array}$ \\
\hline $\mathrm{T}_{1}$ & 0.00 & 0.00 & 0.04 & 0.05 & 0.08 & 0.09 & 0.10 \\
\hline $\mathrm{T}_{2}$ & 0.00 & 0.00 & 0.00 & 0.02 & 0.02 & 0.01 & 0.01 \\
\hline Significance & $\mathrm{ns}$ & $\mathrm{ns}$ & $\mathrm{ns}$ & $\mathrm{ns}$ & $*$ & $*$ & $*$ \\
\hline LSD & - & - & - & - & 0.04 & 0.02 & 0.08 \\
\hline
\end{tabular}

*Denote the significant difference at $\mathrm{P}<0.05$; ns denote the non-significance

Table 5: Effect of AMF base bio-fertilizer on total root dry weight (g) of coconut seedlings

\begin{tabular}{|c|c|c|c|c|c|c|c|}
\hline \multirow[b]{2}{*}{ Treatments } & \multicolumn{7}{|c|}{ Time (after treatment application) } \\
\hline & $\begin{array}{c}1^{\text {st }} \\
\text { Month }\end{array}$ & $\begin{array}{c}2^{\text {nd }} \\
\text { Month }\end{array}$ & $\begin{array}{c}3^{\text {rd }} \\
\text { Month } \\
\end{array}$ & $\begin{array}{c}4^{\text {th }} \\
\text { Month } \\
\end{array}$ & $\begin{array}{c}5^{\text {th }} \\
\text { Month }\end{array}$ & $\begin{array}{c}6^{\text {th }} \\
\text { Month } \\
\end{array}$ & $\begin{array}{c}7^{\text {th }} \\
\text { Month }\end{array}$ \\
\hline $\mathrm{T}_{1}$ & 3.60 & 7.31 & 9.70 & 21.33 & 26.72 & 37.41 & 38.29 \\
\hline $\mathrm{T}_{2}$ & 3.79 & 9.22 & 7.62 & 15.05 & 22.53 & 27.35 & 24.48 \\
\hline Significance & ns & ns & ns & ns & $*$ & $*$ & $*$ \\
\hline LSD & - & - & - & - & 3.84 & 8.21 & 7.65 \\
\hline
\end{tabular}

*Denote the significant difference at $\mathrm{P}<0.05$; ns denote the non-significance

Table 6: Effect of AMF base bio-fertilizer on primary root volume (ml) of coconut seedlings

\begin{tabular}{|c|c|c|c|c|c|c|c|}
\hline \multirow{2}{*}{ Treatments } & \multicolumn{7}{|c|}{ Time (after treatment application) } \\
\cline { 2 - 8 } & $\begin{array}{c}1^{\text {st }} \\
\text { Month }\end{array}$ & $\begin{array}{c}2^{\text {nd }} \\
\text { Month }\end{array}$ & $\begin{array}{c}3^{\text {rd }} \\
\text { Month }\end{array}$ & $\begin{array}{c}4^{\text {th }} \\
\text { Month }\end{array}$ & $\begin{array}{c}5^{\text {th }} \\
\text { Month }\end{array}$ & $\begin{array}{c}6^{\text {th }} \\
\text { Month }\end{array}$ & $\begin{array}{c}7^{\text {th }} \\
\text { Month }\end{array}$ \\
\hline $\mathrm{T}_{1}$ & 29.25 & 45.75 & 48.75 & 113.90 & 111.50 & 134.00 & 132.0 \\
\hline $\mathrm{T}_{2}$ & 26.00 & 44.25 & 48.50 & 77.00 & 102.00 & 99.25 & 101.0 \\
\hline Significance & ns & ns & ns & ns & ns & $*$ & $*$ \\
\hline LSD & - & - & - & - & - & 18.8 & 22.4 \\
\hline
\end{tabular}

*Denote the significant difference at $\mathrm{P}<0.05$; ns denote the non-significance 
untreated plants. The differences were significant from up to the fifth month. The secondary root volume of plants grown with and without mycorrhizal inoculation were not significantly different $(\mathrm{P}<0.05)$ during first five months (Table 7). After fifth month, plants with inoculation $\left(T_{1}\right)$ had a significantly higher root volume when compared to non-inoculated plants until the seventh month. Furthermore, seedlings treated with the inoculum had comparatively higher root volumes at all samplings from fifth to seventh months.

Tertiary root volumes of the inoculated and non-inoculated plants were not significantly different $(\mathrm{P}<0.05)$ during the sixth and seventh months (Table 8). In general, seedlings treated with inoculum had comparatively higher root volumes when compared to non-treated seedlings at the time of field planting.

No quaternary roots were observed during the entire experimental period in non-inoculated seedlings $\left(\mathrm{T}_{2}\right)$. After the sixth month, inoculated seedlings had significantly higher quaternary root volumes (Table 9).

The total root volumes of seedlings grown with and without mycorrhizal inoculation was not significantly different $(\mathrm{P}<0.05)$ during first four months (Table 10). From the fourth month onwards, seedlings with the inoculum had a significantly higher total root volume.

\section{Effect of AMF base bio-fertilizer on shoot} growth of coconut seedlings

During the experimental period, leaf area and shoot dry weight was measured and it was significantly changed $(\mathrm{P}<0.05)$ during the last two months of the experimental period (Table 11 and 12). Leaf area of seedlings was not significantly different between two treatments $(\mathrm{P}<0.05)$ during the first five months of nursery period (Table 11). However, seedling treated with inoculums had higher leaf areas when compared to non-treated seedlings except in the first three months.

The similar phenomenon also observed with shoot dry weight; mean value of shoot dry weight was enhanced by $20.4 \%$ when AMF based bio fertilizer was applied treatment $\left(T_{1}\right)$
(Table 12). Significantly higher shoot dry weights were observed at the end of the nursery period ( $6^{\text {th }}$ and $7^{\text {th }}$ months) in seedlings grown with inoculums compared to seedlings without inoculum (Table 12). In selecting high quality vigorous seedlings, broad and well spread leaves, stout stems, and short petioles are considered desirable characteristics. However, seedlings grown with inoculums always showed greater shoot dry weight when compared to seedlings grown without the inoculum in whole nursery period.

\section{Effect of AMF base bio-fertilizer on shoot growth of field establishment coconut seedlings}

Growth of coconut seedlings are expressed as seedling girth $(\mathrm{cm})$ and the rate of leaf production (number of leaves per month) in Tables, 13 and 14. Application of AMF based bio fertilizer significantly increased $(\mathrm{P}<0.05)$ the girth and the leaf production rate of the coconut seedlings compared to control treatment in the field experiment.

Rate of leaf production did not show any significance between treatments in first 18 months period (Table 14). However, the highest rate of leaf production and seedling girth were recorded from $\mathrm{T}_{3}$ and were significantly different from control treatment $\left(\mathrm{T}_{5}\right)$.

\section{Discussion}

This study was intended to assess the impact of an AMF based bio fertilizer (MYCOgold) on the root and shoot development of the coconut seedlings at nursery stage and in the field conditions. The results revealed that the AMF based bio fertilizer had a positive effect on root growth of coconut seedlings. Auge (2001) reported that plants treated with AMF inoculation have deeper and more extensive root systems. Moreover, Berta et al., (1993) and Espeletaet al., (1999) reported that AM colonization can change specific root length, root architecture and root/shoot ratio of Prunuscerasifera as observed in this study. Although, the AMF based biofertilizer positively affected on root growth, the beneficial impact on shoot growth was marginal. Seedling leaf area 
Table 7: Effect of AMF base bio-fertilizer on secondary root volume (ml) of coconut seedlings

\begin{tabular}{|c|c|c|c|c|c|c|c|}
\hline \multirow[b]{2}{*}{ Treatments } & \multicolumn{7}{|c|}{ Time (after treatment application) } \\
\hline & $\begin{array}{c}1^{\text {st }} \\
\text { Month }\end{array}$ & $\begin{array}{c}2^{\text {nd }} \\
\text { Month } \\
\end{array}$ & $\begin{array}{c}3^{\text {rd }} \\
\text { Month } \\
\end{array}$ & $\begin{array}{c}4^{\text {th }} \\
\text { Month }\end{array}$ & $\begin{array}{c}5^{\text {th }} \\
\text { Month }\end{array}$ & $\begin{array}{c}6^{\text {th }} \\
\text { Month }\end{array}$ & $\begin{array}{c}7^{\text {th }} \\
\text { Month }\end{array}$ \\
\hline $\mathrm{T}_{1}$ & 8.00 & 6.25 & 11.00 & 26.50 & 35.50 & 42.50 & 40.75 \\
\hline $\mathrm{T}_{2}$ & 4.80 & 15.00 & 11.50 & 19.00 & 23.25 & 32.75 & 33.50 \\
\hline Significance & ns & ns & ns & ns & ns & * & * \\
\hline LSD & - & - & - & - & - & 7.8 & 5.4 \\
\hline
\end{tabular}

*Denote the significant difference at $\mathrm{P}<0.05$; ns denote the non-significance

Table 8: Effect of AMF base bio-fertilizer on tertiary root volume (ml) of coconut seedlings

\begin{tabular}{|c|c|c|c|c|c|c|c|}
\hline \multirow{2}{*}{ Treatments } & \multicolumn{7}{|c|}{ Time (after treatment application) } \\
\cline { 2 - 8 } & $\begin{array}{c}1^{\text {st }} \\
\text { Month }\end{array}$ & $\begin{array}{c}2^{\text {nd }} \\
\text { Month }\end{array}$ & $\begin{array}{c}3^{\text {rd }} \\
\text { Month }\end{array}$ & $\begin{array}{c}4^{\text {th }} \\
\text { Month }\end{array}$ & $\begin{array}{c}5^{\text {th }} \\
\text { Month }\end{array}$ & $\begin{array}{c}6^{\text {th }} \\
\text { Month }\end{array}$ & $\begin{array}{c}7^{\text {th }} \\
\text { Month }\end{array}$ \\
\hline $\mathrm{T}_{1}$ & 0.35 & 2.75 & 2.70 & 5.75 & 5.20 & 8.90 & 10.50 \\
\hline $\mathrm{T}_{2}$ & 0.10 & 4.30 & 4.50 & 3.75 & 4.05 & 4.25 & 5.06 \\
\hline Significance & $\mathrm{ns}$ & $\mathrm{ns}$ & $\mathrm{ns}$ & $\mathrm{ns}$ & $\mathrm{ns}$ & $*$ & $*$ \\
\hline LSD & - & - & - & - & - & 4.53 & 3.59 \\
\hline
\end{tabular}

*Denote the significant difference at $\mathrm{P}<0.05$; ns denote the non-significance

Table 9: Effect of AMF base bio-fertilizer on quaternary root volume ( $\mathrm{ml})$ of coconut seedlings

\begin{tabular}{|c|c|c|c|c|c|c|c|}
\hline \multirow{2}{*}{ Treatments } & \multicolumn{7}{|c|}{ Time (after treatment application) } \\
\cline { 2 - 8 } & $\begin{array}{c}1^{\text {st }} \\
\text { Month }\end{array}$ & $\begin{array}{c}2^{\text {nd }} \\
\text { Month }\end{array}$ & $\begin{array}{c}3^{\text {rd }} \\
\text { Month }\end{array}$ & $\begin{array}{c}4^{\text {th }} \\
\text { Month }\end{array}$ & $\begin{array}{c}5^{\text {th }} \\
\text { Month }\end{array}$ & $\begin{array}{c}6^{\text {th }} \\
\text { Month }^{\text {th }}\end{array}$ & \begin{tabular}{c}
$7^{\text {Month }}$ \\
\hline $\mathrm{T}_{1}$
\end{tabular} \\
0.00 & 0.00 & 0.00 & 0.00 & 0.60 & 0.980 & 1.25 \\
\hline $\mathrm{T}_{2}$ & 0.00 & 0.00 & 0.00 & 0.00 & 0.00 & 0.00 & 0.00 \\
\hline Significance & $\mathrm{ns}$ & $\mathrm{ns}$ & $\mathrm{ns}$ & $\mathrm{ns}$ & $\mathrm{ns}$ & $*$ & $*$ \\
\hline LSD & - & - & - & - & & 0.78 & 1.171 \\
\hline
\end{tabular}

*Denote the significant difference at $\mathrm{P}<0.05$; ns denote the non-significance 
Table 10: Effect of AMF base bio-fertilizer on total root volume ( $\mathrm{ml})$ of coconut seedlings

\begin{tabular}{|c|c|c|c|c|c|c|c|}
\hline \multirow[b]{2}{*}{ Treatments } & \multicolumn{7}{|c|}{ Time (after treatment application) } \\
\hline & $\begin{array}{c}1^{\text {st }} \\
\text { Month }\end{array}$ & $\begin{array}{c}2^{\text {nd }} \\
\text { Month } \\
\end{array}$ & $\begin{array}{c}3^{\text {rd }} \\
\text { Month } \\
\end{array}$ & $\begin{array}{c}4^{\text {th }} \\
\text { Month }\end{array}$ & $\begin{array}{c}5^{\text {th }} \\
\text { Month }\end{array}$ & $\begin{array}{c}6^{\text {th }} \\
\text { Month }\end{array}$ & $\begin{array}{c}7^{\text {th }} \\
\text { Month }\end{array}$ \\
\hline $\mathrm{T}_{1}$ & 37.60 & 53.25 & 63.20 & 146.15 & 152.80 & 185.40 & 184.50 \\
\hline $\mathrm{T}_{2}$ & 30.90 & 75.30 & 64.50 & 99.75 & 129.30 & 136.25 & 139.56 \\
\hline Significance & ns & ns & ns & ns & * & * & $*$ \\
\hline LSD & - & - & - & - & 18.68 & 40.54 & 36.87 \\
\hline
\end{tabular}

*Denote the significant difference at $\mathrm{P}<0.05$; ns denote the non-significance

Table 11: Effect of AMF base bio-fertilizer on leaf area $\left(\mathrm{cm}^{2}\right)$ of coconut seedling

\begin{tabular}{|c|c|c|c|c|c|c|c|}
\hline \multirow{2}{*}{ Treatments } & \multicolumn{7}{|c|}{ Time (after treatment application) } \\
\cline { 2 - 8 } & $\begin{array}{c}1^{\text {st }} \\
\text { Month }\end{array}$ & $\begin{array}{c}2^{\text {nd }} \\
\text { Month }\end{array}$ & $\begin{array}{c}3^{\text {rd }} \\
\text { Month }\end{array}$ & $\begin{array}{c}4^{\text {th }} \\
\text { Month }\end{array}$ & $\begin{array}{c}5^{\text {th }} \\
\text { Month }\end{array}$ & $\begin{array}{c}6^{\text {th }} \\
\text { Month }^{\text {th }}\end{array}$ & $\begin{array}{c}7^{\text {th }} \\
\text { Month }\end{array}$ \\
\hline $\mathrm{T}_{1}$ & 310.21 & 571.8 & 795.8 & 1390.0 & 1477.3 & 2041.8 & 2060.9 \\
\hline $\mathrm{T}_{2}$ & 224.99 & 659.2 & 845.6 & 1349.1 & 1340.8 & 1820.1 & 1394.9 \\
\hline Significance & ns & ns & ns & ns & ns & $*$ & $*$ \\
\hline LSD & - & - & - & - & - & 184.35 & 413.55 \\
\hline
\end{tabular}

*Denote the significant difference at $\mathrm{P}<0.05$; ns denote the non-significance

Table 12: Effect of AMF base bio-fertilizer on shoot dry weight (g) of coconut seedling

\begin{tabular}{|c|c|c|c|c|c|c|c|}
\hline \multirow[b]{2}{*}{ Treatments } & \multicolumn{7}{|c|}{ Time (after treatment application) } \\
\hline & $\begin{array}{c}1^{\text {st }} \\
\text { Month }\end{array}$ & $\begin{array}{c}2^{\text {nd }} \\
\text { Month }\end{array}$ & $\begin{array}{c}3^{\text {rd }} \\
\text { Month }\end{array}$ & $\begin{array}{c}4^{\text {th }} \\
\text { Month }\end{array}$ & $\begin{array}{c}5^{\text {th }} \\
\text { Month }\end{array}$ & $\begin{array}{c}6^{\text {th }} \\
\text { Month }\end{array}$ & $\begin{array}{c}7^{\text {th }} \\
\text { Month }\end{array}$ \\
\hline $\mathrm{T}_{1}$ & 12.87 & 23.51 & 28.89 & 47.90 & 66.99 & 88.23 & 105.60 \\
\hline $\mathrm{T}_{2}$ & 15.87 & 28.13 & 28.07 & 60.71 & 59.29 & 67.13 & 87.73 \\
\hline Significance & ns & ns & ns & ns & ns & $*$ & * \\
\hline LSD & - & - & - & - & - & 10.56 & 12.58 \\
\hline
\end{tabular}

*Denote the significant difference at $\mathrm{P}<0.05$; ns denote the non-significance 
Table 13: Effect of AMF base bio-fertilizer on seedling girth $(\mathrm{cm})$ of coconut seedlings

\begin{tabular}{|l|c|c|c|c|}
\hline \multicolumn{1}{|c|}{ Treatments } & \multicolumn{4}{c|}{ Seedling girth (cm) } \\
\cline { 2 - 5 } & Nov 2012 & May 2013 & Nov 2013 & Jun 2014 \\
\hline $\mathrm{T}_{1}$. Bio-fertilizer+ 25 \% YPM mixture & $12.30 \mathrm{a}$ & $24.2 \mathrm{a}$ & $40.84 \mathrm{a}$ & $57.8 \mathrm{a}$ \\
$\mathrm{T}_{2}$. Bio-fertilizer + 50 \% YPM mixture & $10.56 \mathrm{a}$ & $28.2 \mathrm{a}$ & $38.60 \mathrm{a}$ & $54.6 \mathrm{a}$ \\
$\mathrm{T}_{3}$. Bio-fertilizer + 75 \% YPM mixture & $10.66 \mathrm{a}$ & $25.0 \mathrm{a}$ & $39.60 \mathrm{a}$ & $61.0 \mathrm{a}$ \\
$\mathrm{T}_{4}$. Bio-fertilizer+ 100 \% YPM mixture & $10.68 \mathrm{a}$ & $21.4 \mathrm{a}$ & $36.08 \mathrm{ab}$ & $50.8 \mathrm{a}$ \\
$\mathrm{T}_{5}$ Only YPM mixture & $10.86 \mathrm{a}$ & $17.8 \mathrm{a}$ & $28.80 \mathrm{~b}$ & $34.6 \mathrm{~b}$ \\
Significance & $\mathrm{ns}$ & $\mathrm{ns}$ & $*$ & $*$ \\
L.S.D. & - & - & 8.5 & 17.09 \\
\hline
\end{tabular}

In each column, values with the same letter are not significantly different at $\mathrm{P}<0.05$ (LSD)

*Denote the significant difference at $\mathrm{P}<0.05$; ns denote the non-significance

Table 14: Effect of AMF base bio-fertilizer on rate of leaf production of coconut seedlings

\begin{tabular}{|l|c|c|c|c|}
\hline \multirow{2}{*}{ Treatments } & \multicolumn{3}{|c|}{ Rate of leaf production (Leaf number per month) } \\
\cline { 2 - 5 } & Nov 2012 & May 2013 & Nov 2013 & Jun 2014 \\
\hline $\mathrm{T}_{1}$. Bio-fertilizer+ 25 \% YPM mixture & - & $0.44 \mathrm{a}$ & $0.52 \mathrm{a}$ & $0.54 \mathrm{~b}$ \\
$\mathrm{~T}_{2}$. Bio-fertilizer + 50 \% YPM mixture & - & $0.42 \mathrm{a}$ & $0.58 \mathrm{a}$ & $0.57 \mathrm{~b}$ \\
$\mathrm{~T}_{3}$. Bio-fertilizer + 75 \% YPM mixture & - & $0.44 \mathrm{a}$ & $0.54 \mathrm{a}$ & $0.68 \mathrm{a}$ \\
$\mathrm{T}_{4}$. Bio-fertilizer+ $100 \%$ YPM mixture & - & $0.45 \mathrm{a}$ & $0.51 \mathrm{a}$ & $0.65 \mathrm{a}$ \\
$\mathrm{T}_{5}$ Only YPM mixture & - & $0.36 \mathrm{a}$ & $0.43 \mathrm{a}$ & $0.42 \mathrm{c}$ \\
Significance & - & $\mathrm{ns}$ & $\mathrm{ns}$ & $*$ \\
L.S.D. & - & - & - & 0.07 \\
\hline
\end{tabular}

In each column, values with the same letter are not significantly different at $\mathrm{P}<0.05$ (LSD)

*Denote the significant difference at $\mathrm{P}<0.05$; ns denote the non-significance

Table 15: Recommended Inorganic fertilizer mixture (grams per palm) for young coconut palms by Coconut Research Institute of Sri Lanka (wet and intermediate zones)

\begin{tabular}{|c|c|c|c|c|c|c|c|c|}
\hline \multirow[b]{2}{*}{ Fertilizer } & \multicolumn{8}{|c|}{ Age of palm } \\
\hline & 6 months & 1 year & 1.5 year & 2 year & 2.5 year & 3 year & 3.5 year & $\begin{array}{l}4 \text { year } \\
\text { up to } \\
\text { bearing }\end{array}$ \\
\hline Urea & 190 & 235 & 235 & 305 & 305 & 375 & 375 & 470 \\
\hline Eppawala Rock phosphate & 420 & 530 & 530 & 690 & 690 & 850 & 850 & 1060 \\
\hline Muriate of potash & 190 & 235 & 235 & 305 & 305 & 375 & 375 & 470 \\
\hline Dolomite & 500 & 500 & 500 & 500 & 500 & 500 & 500 & 500 \\
\hline
\end{tabular}

Reference: Coconut Research Institute Advisory Circular No A 5 
and shoot dry weight of the coconut seedlings showed significant differences at the latter part of the nursery period. These results conform to those of Wu et al., (2011) who observed that the enhanced efficacy of mycorrhizas was more obvious for root than for shoot or total dry weight of Peach (Prunuspersica L. batsch) seedlings. In addition, these results agree with those of with the findings of Yao et al (2005) in Litchi (Litchi chinensis) and Wu et al., (2007) in red tangerine (Citrus tangerine). George (2000) reported AMF bio fertilizers increase the effective absorptive area of roots by formation of an extensive extractible hypha network that enhances efficiency in absorption of nutrients.

The higher root growth of primary, secondary, tertiary and quaternary by biofertilizer treatments improves the efficient water uptake and nutrient absorption and it leads to develop a good quality coconut seedling. However, the increase in shoot development is also a beneficial character for a seedling because it increases photosynthesis rates and dry matter production which is helpful to root and shoot growth of the plant. However, having a balanced shoot/root ratio is important for a seedling to obtain a better partitioning of dry matter.

\section{Conclusion}

The present study illustrated that the application of an AMF based bio fertilizer (MYCOgold) had no significant effect on selected root growth parameters in the early stages (up to third month). However, it increased the volumes and dry weights of primary, secondary, tertiary and quaternary roots and stem girth at the latter stages of coconut seedling growth. The leaf area and shoot dry weight were significantly increased by the AMF based bio fertilizer at the end of the nursery period. A significantly higher leaf production rate and stem girth was observed in the field established seedlings treatment with $500 \mathrm{~g}$ of AMF based biofertilizer with 75\% YPM. Therefore, application of the amount of inorganic fertilizer can be reduced with applying AMF based bio fertilizers in coconut plantations. The experiment concluded that application of bio fertilizer is beneficial for coconut seedlings in the nursery for the production good quality seedlings with well-developed roots resulting in better field establishment and in the field for fast and vigorous growth.

\section{References}

Atimanav, G. and Adholeya, A. 2002. AM inoculation of five tropical fodder crops and inoculum production in unfertilized soil amended with organic matter. Biol. And Fert. of Soil, 35: 214-218.

Auge, R. M. 2001. Water relations, drought and vesicular - arbuscular mycorrhizal symbiosis. Mycorrhiza, 11: 3-42.

Berta, G., Fusconi, A. and Trotta, A. 1993. VA mycorrhizal infection and the morphology and function of root systems. Journal of Environmental Botany 33: 159-173.

Burdette, A.M. 1979. A non-destructive method for measuring the volume of intact plant parts.Canadian Journal of Forest Research, 9: $120-122$.

Castellano, M.A. and Molina, R. 1989. Mycorrhizae. In: Landis, T.D.; Tinus, R.W.; McDonald, S.E.; Barnett, J.P. The Container Tree Nursery Manual, Volume 5. Agric. Handbook. 674. Washington, DC: U.S. Department of Agriculture, Forest Service: 101-167.

Coyne, J. and Mark, H. 1999. Soil Microbiology: An Exploratory Approach. Delmar Publishers. Albany, New York.

Espeleta J.F., Eissenstat, D.M. and Graham, J. H. 1999. Citrus root responses to localized drying soil: a new approach to studying mycorrhizal effects on the roots of mature trees. Plant and Soil 206: 1-10.

Gemma, J.L. and Koske, R.E. 2006. Use of Mycorrhizae in Restoration of Hawaiian Habitats. Hawaii Conservation Alliance. [online] Available at http://www.rngr.net/ Publications /ctnm. [Accessed at May 17, 2006].

George, E. 2000. Nutrients uptake, ppg. 288307. In Y. Kapulink and D.D. Douds. Jr. (eds). Abuscular Mycirrhizas: Physiology 
and function. Kulwer Acadamic publishers, Netherland.

Gianinazzi, S., Schuepp, H., Barea, J.M., and Haselwandter, K. 2002. Mycorrhizal Technology in Agriculture: From Genes to Bioproducts. Birkha"user, Basel, pp. 296.

Jeffries, P. and Barea, J.M. 2000. Arbuscular mycorrhiza key component of sustainable plant-soil ecosystems. In: Hock, B. (Ed.). The Mycota, Volume IX. Fungal Associations. Springer-Verlag, pp. 95113.

Kemery, R.D. and Dana, M.N. 1995. Prairie Remnant Soil as a Source of Myorrhizal Inoculums. Horticulture Science 30 (5):1015-1016.

Linderman, R.G. and Davis, E.A. 2004. Evaluation of Commercial Inorganic and Organic Fertilizer Effects on Arbuscular Mycorrhizae Formed by Glomusintraradices. Horticulture Technology 14 (2) 196-202.

Mapa, R.B., Dassanayake, A.R. and Nayakekorale, H.B. 2005. Soils of the Intermediate zone of Sri Lanka: morphology, characterization and classification. Soil Science Society of Sri Lanka, Peradeniya, Sri Lanka.

Marx, D.H., Cordeia, C.E., Manul, S. B. and Ruehle, J.L. 1989. Ectomycorrhizal development on pine by Pisolithustinctorius in bare-root and container seeding nurseries. 1. Efficiency of various vegetative inoculums formulations. New Forests 3: 45-56.
Menon, K.P.V. and Pandalai, K.M. 1958. The coconut palm; A Monograph, Indian Central Coconut Committee, South India.

Miller, R.M. and Jastrow, J.D. 1992. The applicatio1991n of VA mycorrhizae to ecosystem restoration and reclamation. In: Allen, M.F. (Ed.), Mycorrhizal Functioning. Chapman \& Hall, Ltd., London, England, pp. 438-467.

[SAS] Statistical Analysis Systems, 1999.SAS 1, STAT Users Guide, Release, 7.00 Cary, NC: Statistical Analysis Systems Institute, 1028.

Wu, Q. S., Zou, Y.N., Xia, R.X. and Wang, M. Y. 2007. Five Glomus species affect water relations of Citrus tangerine during drought stress. Experimental Botany, 48:147-154.

Wu, Q.S., Li, G.H. and Zou, Y.N. 2011. Roles of arbuscular mycorrhizal fungion growth and nutrient acquisition peach (Prunuspersica L. BATSCH) seedlings, The Journal of Animal \& Plant Sciences, 21(4): 746-750.

Yao, Q., Zhu, H.H. and Chen, J.Z. 2005. Growth responses and endogenous IAA and iPAs changes of litchi (Litchi chinensis Sonn.) seedlings induced by arbuscular mycorrhizal fungal inoculation. Horticulture Science 105:145-151. 